\title{
Tectonic significance of magnetic susceptibility fabrics in Plio-Quaternary mudstones of southwestern foothills, Taiwan
}

\author{
Teh-Quei Lee ${ }^{1}$ and Jacques Angelier ${ }^{2}$ \\ ${ }^{1}$ Institute of Earth Sciences, Academia Sinica, P.O. Box 1-55, Nankang, Taipei, Taiwan, 115, R.O.C. \\ ${ }^{2}$ Université P-M Curie, Dépt. de Géotectonique (ESA 7072), Tectonique Quantitative, 4 place Jussieu, T25-26, E-1, 75252 Paris Cédex, France
}

(Received February 15, 1999; Revised July 17, 2000; Accepted July 28, 2000)

\begin{abstract}
Anisotropy of magnetic susceptibility (AMS) was studied in three Plio-Pleistocene turbiditic mudstone sequences accumulated in the foreland basin of southwestern Taiwan. These formations were incorporated in the front units of the collision belt and underwent folding and thrusting during the last 2 Ma. Five types of fabrics were identified from more than 3,000 samples collected in 352 sites, with 251 sites allowing determination of a magnetic lineation. NNE-SSW trends are predominant, minor N-S and NE-SW trends are present. Magnetic lineations are widespread in the lower section where folds are tight, and scarce in the youngest sediments where folds are gentle. The strong correlation between the structural features and the AMS orientations suggests a tectonic origin for most magnetic lineations superimposed on the initial flattening that results from sediment compaction. This is confirmed by tectonic studies based on structural analysis and paleostress tensor reconstructions. The tectonic studies reveal a major WNW-ESE compression, which provide orientations of compressive tectonic regimes consistent for resulting the magnetic lineations. In contrast, the hypothesis of a sedimentary origin can be ruled out in most cases, because the orientations of magnetic lineations and those of depositional fabrics (paleocurrents, sediment supply directions and even slumps) are oblique at a variety of angles. Furthermore, based on magnetostratigraphy, we conclude that this compression culminated about 0.9-1 Ma ago. Earlier minor events, NW-SE and W-E compression, have also been found and we propose that they have occurred in approximately 1 and $2 \mathrm{Ma}$ ago, respectively. Thus, the main cause of AMS trend is thought to be the WNW-ESE Quaternary compression responsible for major folding and thrusting. In addition, the magnetic fabric of tectonic origin is absent, or poorly marked, in formations younger than about 0.9 Ma to the north. However, it is still recognized but decreased after about $0.7 \mathrm{Ma}$ ago to the south. This indicates that the WNW-ESE compression propagated southward between 0.9 and $0.7 \mathrm{Ma}$ ago, consistent with the migration of folding and thrusting during the last Taiwan collision.
\end{abstract}

\section{Introduction}

The analysis of the anisotropy of magnetic susceptibility (AMS) has been applied to rock fabric investigation. The most successful application of AMS analysis dealt with studies of ductile deformation of rocks. Several papers showed that magnetic fabric provides a reliable strain indicator (Graham, 1966; Henry, 1973; Hrouda, 1979; Hrouda and Janak, 1976; Hrouda et al., 1978; Kligfield et al., 1977, 1982). During the last ten years, the AMS analysis was also employed to study the fabric of deformed successions, especially in fold-and-thrust belts in compressional field. In Taiwan, it was found that despite limited strain the magnetic lineations formed in the late Cenozoic sedimentary rocks were generally perpendicular to regional compression (Kissel et al., 1986; Lee et al., 1990).

Collision has occurred since the late Miocene in Taiwan, at the boundary between the Philippine Sea plate and the Eurasian continental plate. The characteristics of the Taiwan belt have been described by many authors in terms of regional geology (Ho, 1986), geophysics (Tsai, 1986), structural de-

Copy right(C) The Society of Geomagnetism and Earth, Planetary and Space Sciences (SGEPSS); The Seismological Society of Japan; The Volcanological Society of Japan; The Geodetic Society of Japan; The Japanese Society for Planetary Sciences. velopment (Suppe, 1981) and tectono-sedimentary evolution (Teng, 1990). Various models were presented to explain the origin of the main units in the belt (Lu and Hsu, 1992).

AMS studies have been carried out in the Plio-Pleistocene successions at the Coastal Range of eastern Taiwan (Lee et al., 1990). Also paleomagnetic studies revealed that a diachronic clockwise rotation had affected the units of the Coastal Range in eastern Taiwan, occurring successively from north to south during the last $3 \mathrm{Ma}$ (Lee, 1989; Lee et al., 1991a). This phenomenon is consistent with the oblique collision of the Luzon Arc against the Central Range of Taiwan, also migrating from north to south as revealed by geodynamic studies (Suppe, 1981). Taking these rotations into account, Kissel et al. (1986) and Lee et al. (1990) showed that the magnetic anisotropy acquired by the deformed marine successions was consistent with, and related to, the compression oriented NW-SE to WNW-ESE in this region (Barrier and Angelier, 1986). Late Cenozoic rotations were identified not only in the Coastal Range, but also in northern Taiwan (Lee et al., 1991b; Lue et al., 1995). There the rotation history is consistent with the tectonic evolution of the sharply bent segment of the collision belt (Lu et al., 1995).

Thick mudstone sequences accumulated during the Late Cenozoic in the foreland basin of southwestern Taiwan (Ho, 


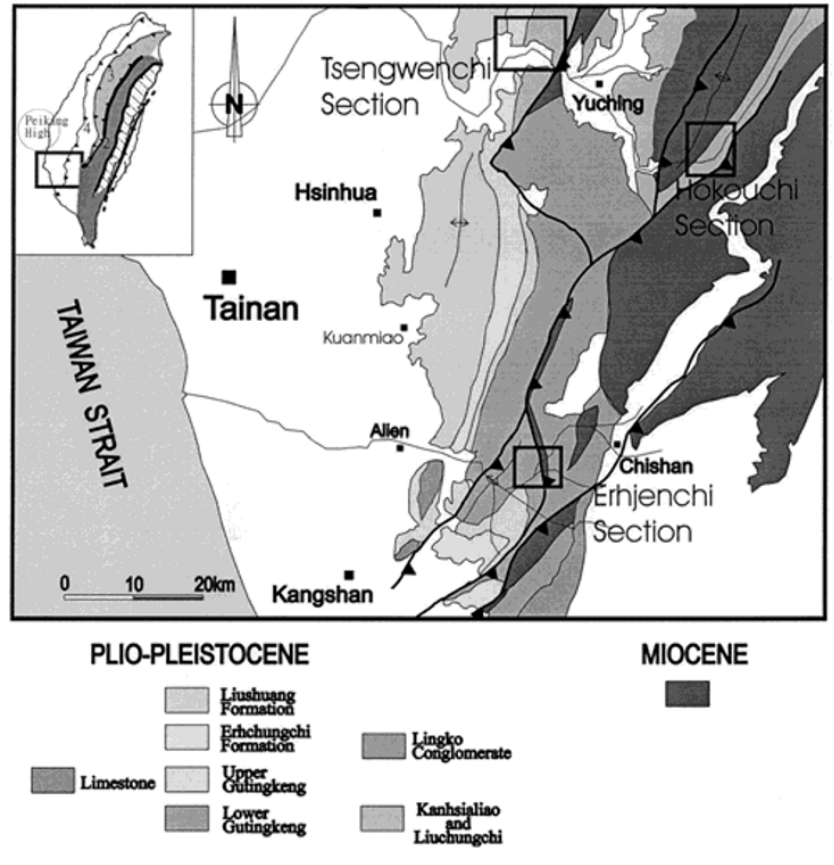

Fig. 1. The southwestern Foothills: location in Taiwan and simplified map of the area studied. Small rectangles indicate location of the three sections and refer to maps of Figs. 2, 3 and 4. Numbers shown in the index map are: (1) Coastal Range which is thought to be the northern part of Luzon arc; (2) Central Range; (3) Hsuehshan Range and (4) western Foothills.

1988). They were incorporated in the front units of the collision belt during the Plio-Pleistocene time and they underwent folding and reverse faulting mainly related to the PleistoceneHolocene compressional event. The previous AMS results showed that magnetic lineation trends have different orientations at different horizons in the Tsengwenchi and Hokouchi sections (Lee and Horng, 1990, 1993). What the significance of it needs to be determined. Paleomagnetic results from the Tsengwenchi section suggested that a rotation of about $20^{\circ}$ clockwise may have affected the Pleistocene sediments older than 0.98 Ma (Horng, unpubl. Ph.D. dissertation, 1991). Unfortunately, these determinations are questionable because of the nature of the magnetic minerals used (greigite). Determinations made with magnetite in the Pliocene sediments in age (which should have experienced this rotation) did not reveal any significant rotation according to Horng (1991). Thus, it seems that significant rotations does not take place during the Quaternary.

In this paper, we principally analyze the distribution and tectonic significance of the AMS in the Pliocene and the Pleistocene thick mudstones, which underwent folding and thrusting during the last $2 \mathrm{Ma}$ in the Western Foothills of the southern Taiwan belt. Our AMS analysis aims first to describe patterns of magnetic lineation with better age control through combining magnetostratigraphic and biostratigraphic data. Second, our AMS analysis aims at better understanding the origin of magnetic fabrics. This required consideration of different possible factors: deposition, compaction, and tectonic deformation. Particular attention was paid to syndepositional sedimentary structures in the mudstone succession, because they are numerous and may have influenced the AMS. On the other hand, a study for fault- ing and foldings was carried out independently in the same sections. As for syndepositional features, this analysis of tectonic structures was indispensable in order to confirm, or rule out, the influence of tectonism in the AMS. Finally, the results of our AMS analyses are examined in light of the tectonic evolution of the foreland basin of southwestern Taiwan.

\section{Geological Framework}

The Plio-Pleistocene mudstone succession is dominated in the southwestern Taiwan. Studies of clay minerals in these mudstone successions tell us highlighted the rapid denudation and sedimentation processes during the mountain building of Taiwan (Chamley et al., 1993). Sandstones and shales are common in the older formations. Continuous exposures are present along the valleys of the Tsengwenchi (Fig. 2), Hokouchi (Fig. 3) and Erhjenchi (Fig. 4), which allow the extensive sampling to be carried out.

The Tsengwenchi section (Fig. 2) is approximately $4 \mathrm{~km}$ long. It cuts perpendicular to the NNE-SSW structural trend, on the footwall of the west vergent Wushantou thrust fault. In this section, the beds dip westward and decreases in dip angle to the west: it averages $60^{\circ}-70^{\circ}$ in the eastern half of the section, and $30^{\circ}-50^{\circ}$ in the western half. Two high angle thrust faults cut this sequence: the west-vergent Wushantou fault itself, and a small east-vergent fault, located about $200 \mathrm{~m}$ west of the Wushantou fault. Nearly vertical beds crop out locally near thrusts. The lithostratigraphic units can be divided into five formations: the Yunshuichi, Liuchungchi, Kanhsialiao, Erchungchi and Liushuang formations in ascending order (Stach, 1957; Chang, 1962). These units comprise mainly dark gray sandy shale, shale and muddy sandstone; the total thickness is about $3,500 \mathrm{~m}$. Based on nannofossil analysis, this sequence is late Pliocene (NN16) to late Pleistocene (NN20) in age (Chi, 1978). Magnetostratigraphic analysis indicated that sediment ages in this section vary continuously from the late Gauss to the Brunhes normal epochs (Horng, unpubl. Ph.D. dissertation, 1991).

The Hokouchi section (Fig. 3) is located approximately 8 $\mathrm{km}$ east of the Tsengwenchi section. It comprises the older succession of late Miocene to Pliocene in age. The beds generally strike NE-SW and dip $30^{\circ}-45^{\circ}$ eastward. The whole sequence studied is located on the eastern side of the Choutouchi fault. Lithostratigraphic units of this sequence are, in ascending order, the Tangenshan Sandstone, the Yenshuikeng Shale, the Ailiaochiao Formation, the Choutouchi Formation and the Peiliao Shale. The Tangenshan sandstone and the Choutouchi Formation are mainly constituted by fine-grained sandstone and muddy sandstone interbedded with thin layered sandy shale. In the other formations, dark-gray shale interbedded with sand shale, yellow-brown sandstone and muddy sandstone are predominant. A biostratigraphical study in the adjacent Kueitanchi section suggested that the Miocene/Pliocene boundary is located within the Tangenshan Sandstone, whereas the Pliocene/Pleistocene boundary is located at the upper part of the Peiliao Shale (Chi, 1978). Thus, the ages in the Hokouchi section range from late Miocene to early Pleistocene.

The Erhjenchi section (Fig. 4) is located about $20 \mathrm{~km}$ south of the other two sections (Fig. 1). It was possible 


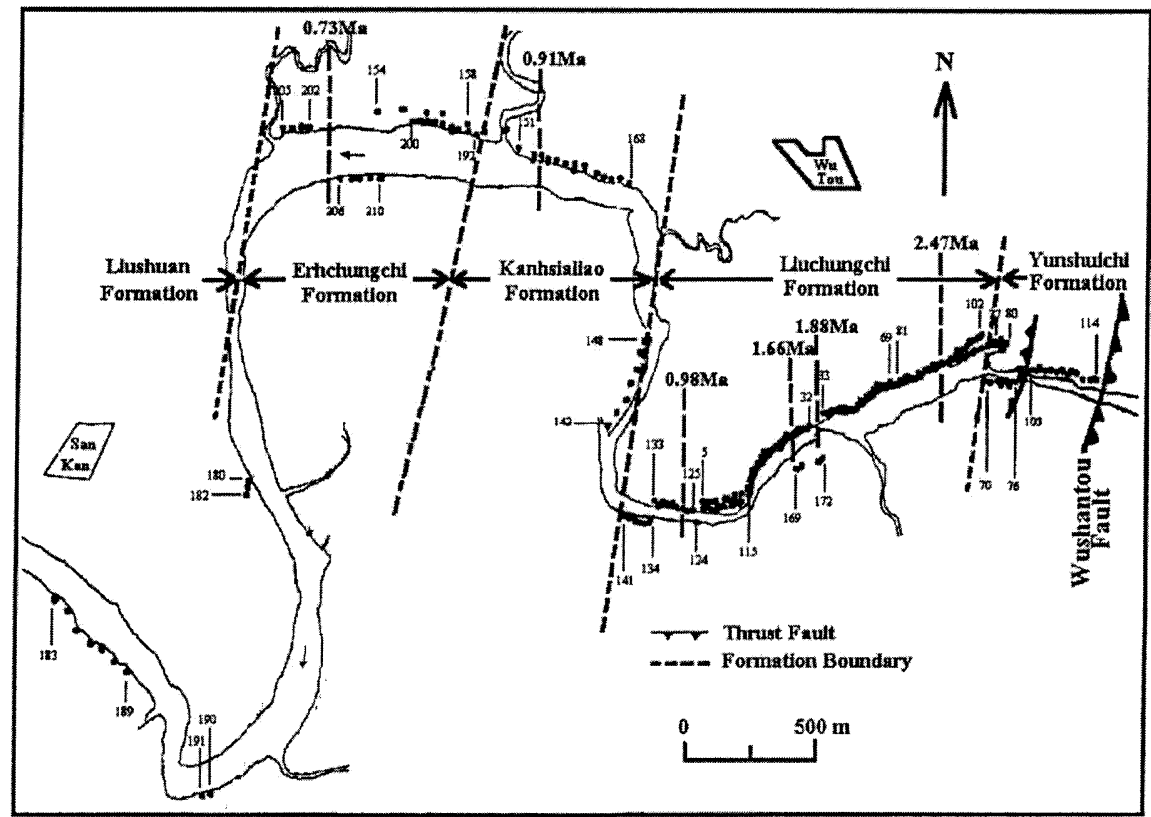

Trend of Magnetic Lineation of Tsengwenchi Section

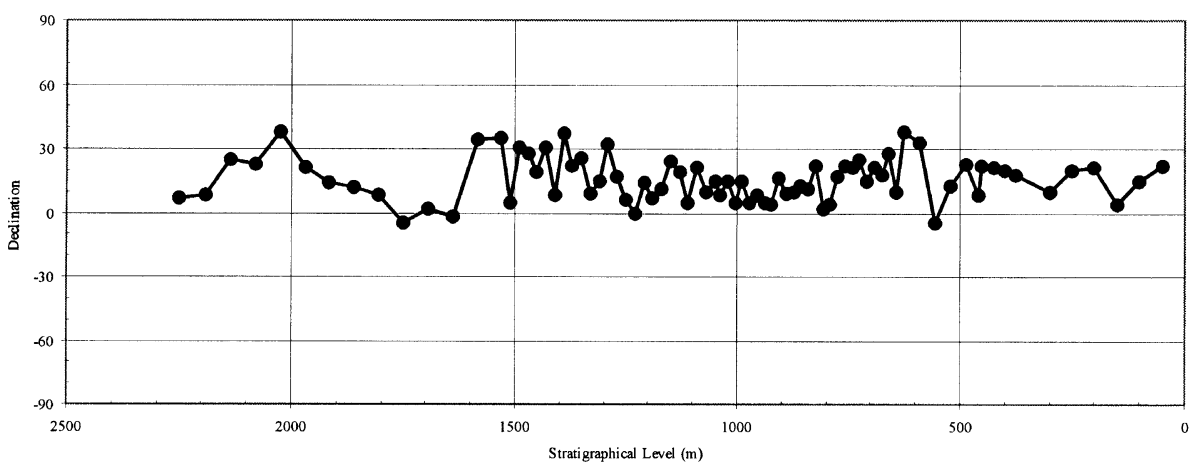

Trend of Proposed Paleostress of Tsengwenchi Section

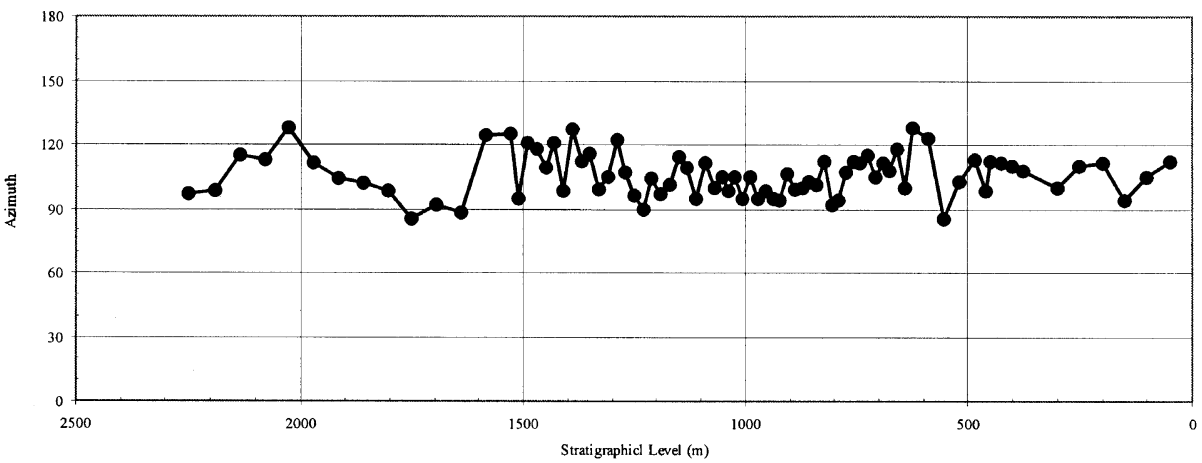

Fig. 2. Location of sampling sites (small dots), magnetic lineation trends and proposed paleostress directions in the Tsengwenchi section (located in Fig. 1) Names of formations and ages in Ma (based on magnetostratigraphic and biostratigraphic analysis) indicated. Origin of stratigraphical level is set at the Wushantou Fault.

to take samples almost continuously from older than $1.7 \mathrm{Ma}$ (in the eastern part of the area) to younger than $0.7 \mathrm{Ma}$ (to the west). The bedding commonly strikes N-S to NNE-SSW, with some NE-SW deviations in the eastern subsections, and dips $50^{\circ}-70^{\circ}$ to the west. The bedding dip decreases from east to west. The oldest layers crop out near the axis of NNE-
SSW trending Hsiaokunshui anticline. To the east, the lower subsection is separated by the Hsiaokunshui Fault. The Erhjenchi section (Fig. 4) corresponds to the Pleistocene lower and upper Gutingkeng Formations. The lower Gutingkeng Formation is mainly constituted by very fine-grained mudstone, whereas in the upper Gutingkeng Formation mudstone 


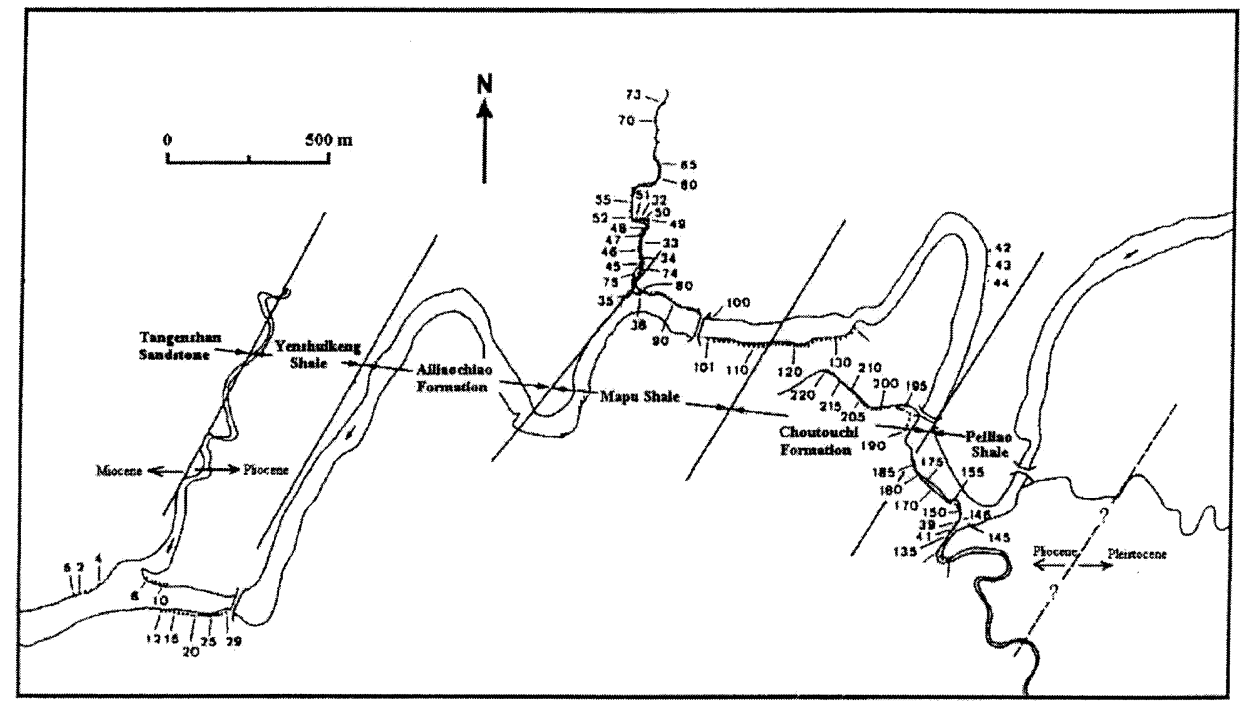

Trend of Magnetic Linetion of Hokouchi Section

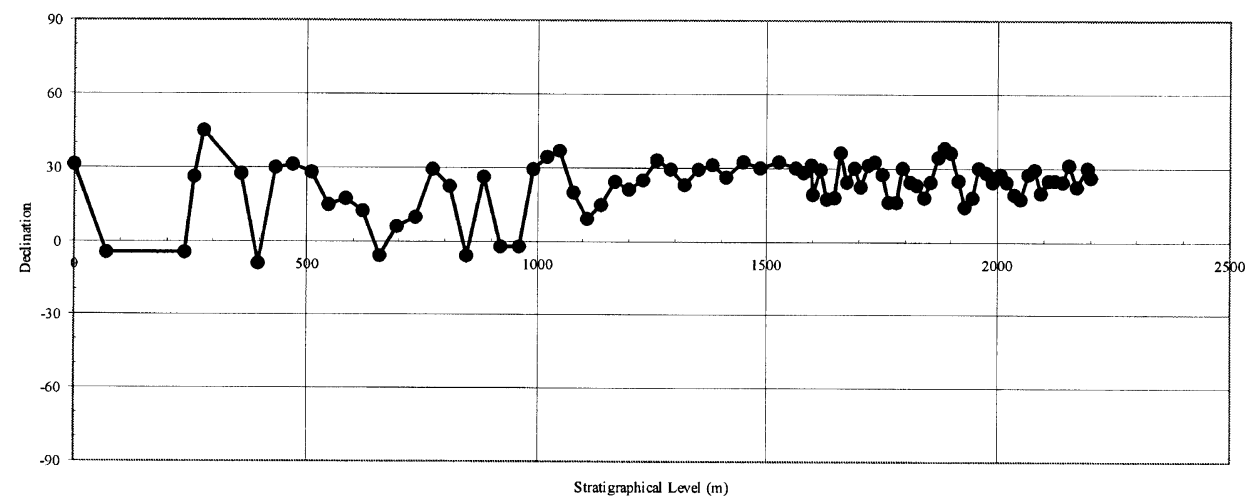

Trend of Proposed Paleostress of Hokouchi Section

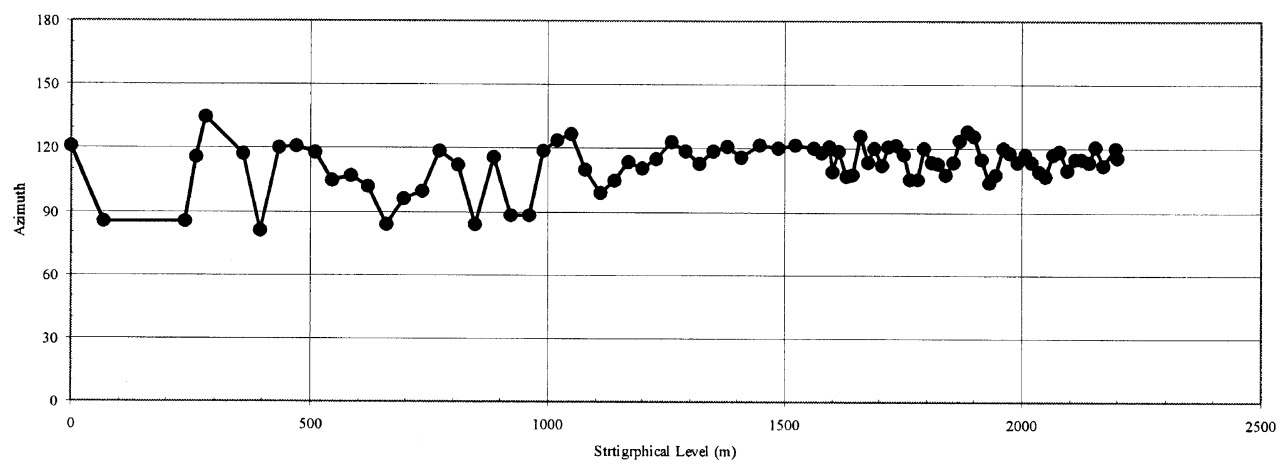

Fig. 3. Location of sampling sites (small dots), magnetic lineation trends and proposed paleostress directions in the Hokouchi section (located in Fig. 1). Names of formations and major stratigraphical boundaries (based on biostratigraphic analysis) indicated. Origin of stratigraphical level is set at the boundary of Tangenshan Sandstone and Yenshuikeng Shale.

and fine-grained sandstone are interbedded. Magnetostratigraphic analyses showed that the lower Gutingkeng Formation ranges from the Olduvai normal event to the BrunhesMatuyama boundary, whereas the upper Gutingkeng Formation deposited during the Brunhes normal epoch (Horng, unpubl. Ph.D. dissertation, 1991).

Magnetic minerals contained in the Tsengwenchi and Erhjenchi sections have been studied. Horng et al. (1992) indicated that the magnetic grains in the formations studied are principally made of magnetite, pyrrhotite and greigite. This magnetic mineralogy was identified based on X-ray diffraction patterns, acquisition of saturation isothermal remanent magnetization (SIRM), and the semi-destructive field of SIRM. Magnetite and pyrrhotite are present throughout the sections, but in variable proportions. Magnetite is abundant in the succession older than 1.6 Ma and pyrrhotite dominates in the younger formations. Greigite is very rare in the older succession of the sections studied, and dominates 


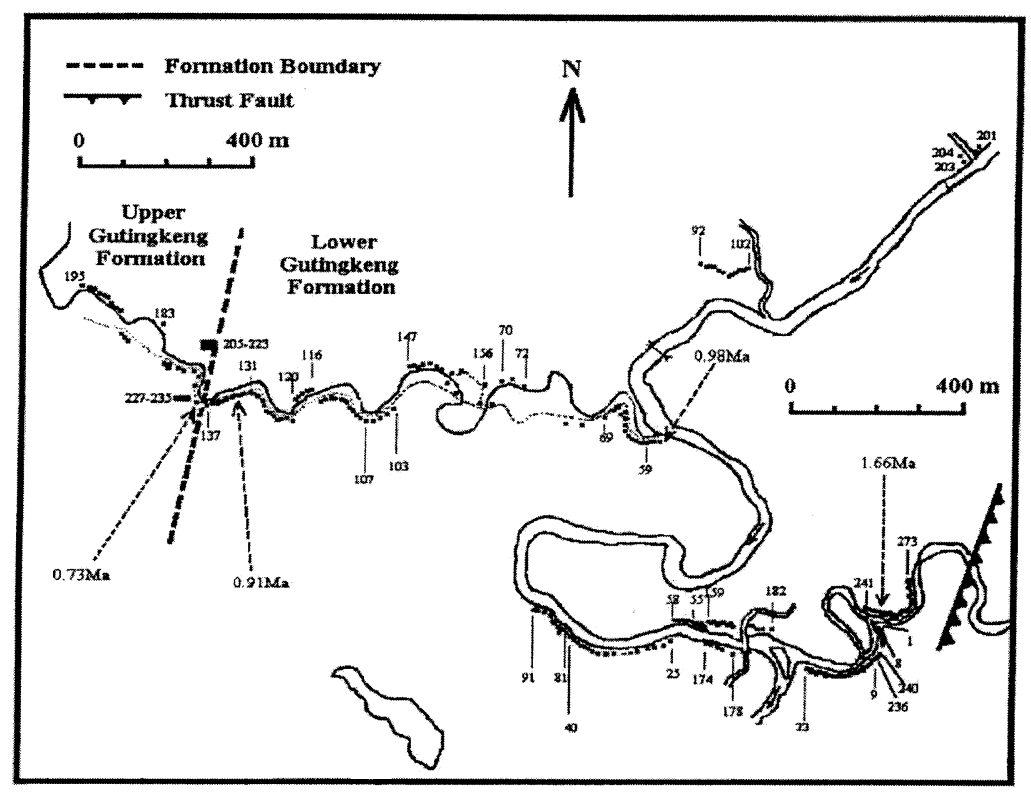

Trend of Magnetic Lineation of Erhjenchi Section

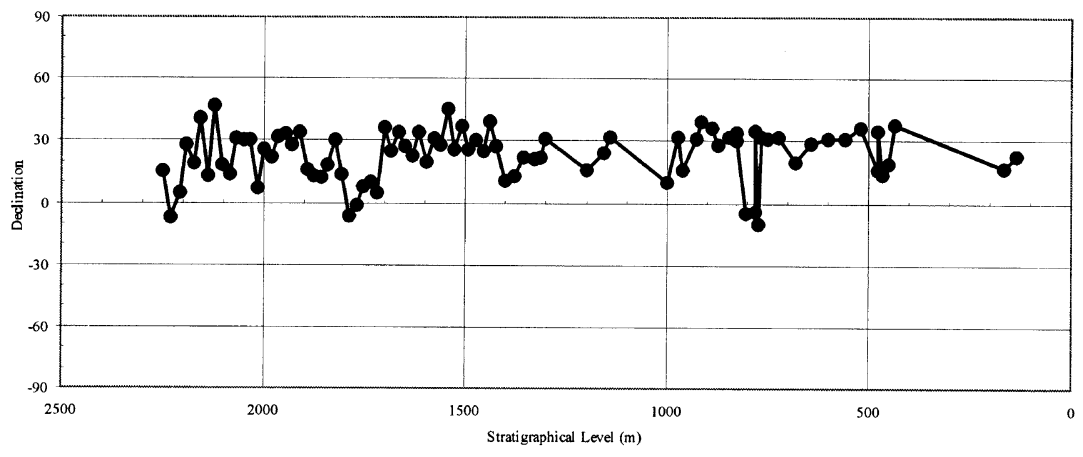

Trend of Proposed Paleostress of Erhjenchi Section

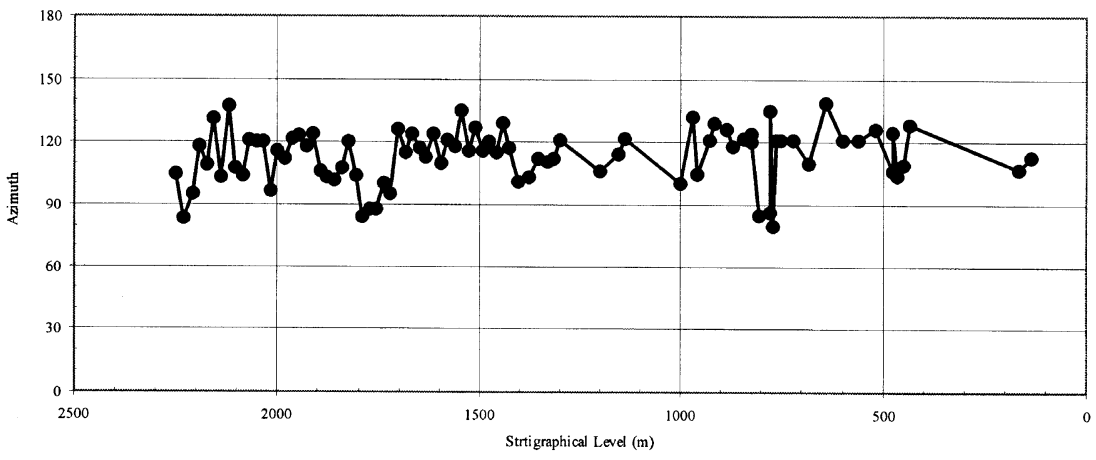

Fig. 4. Location of sampling sites (small dots), magnetic lineation trends and proposed paleostress directions in the Erhjenchi section (located in Fig. 1). Names of formations and ages in Ma (based on magnetostratigraphic and biostratigraphic analysis) indicated. Origin of stratigraphical level is set at the thrust fault shown in the map.

in the formations having the age interval of 1.6-0.7 Ma in age. Magnetite, greigite and pyrrhotite were detrital, mainly provided by rivers from the Central Range, undergoing uplift and erosion, to the marine mudstone basin where a reducing environment prevailed. The magnetic minerals were rapidly deposited in accumulating sediments and chemical transformation was limited. It is known that the present-day sediments of the Taiwan Strait revealed similar situations (Horng, pers. comm., 2000).

\section{Analysis of Magnetic Susceptibility}

\subsection{Methods and results}

More than 3,000 samples from 352 sites collected from the three major sections (Fig. 1) were subjected to analyze the anisotropy of magnetic susceptibility (AMS). Each sample was cut into several specimens of $22 \mathrm{~mm}$ in length and 25.4 $\mathrm{mm}$ in diameter. At each sampling site, at least five specimens were chosen and 3 to 23 successful AMS determinations were obtained. The bulk susceptibility and anisotropy 

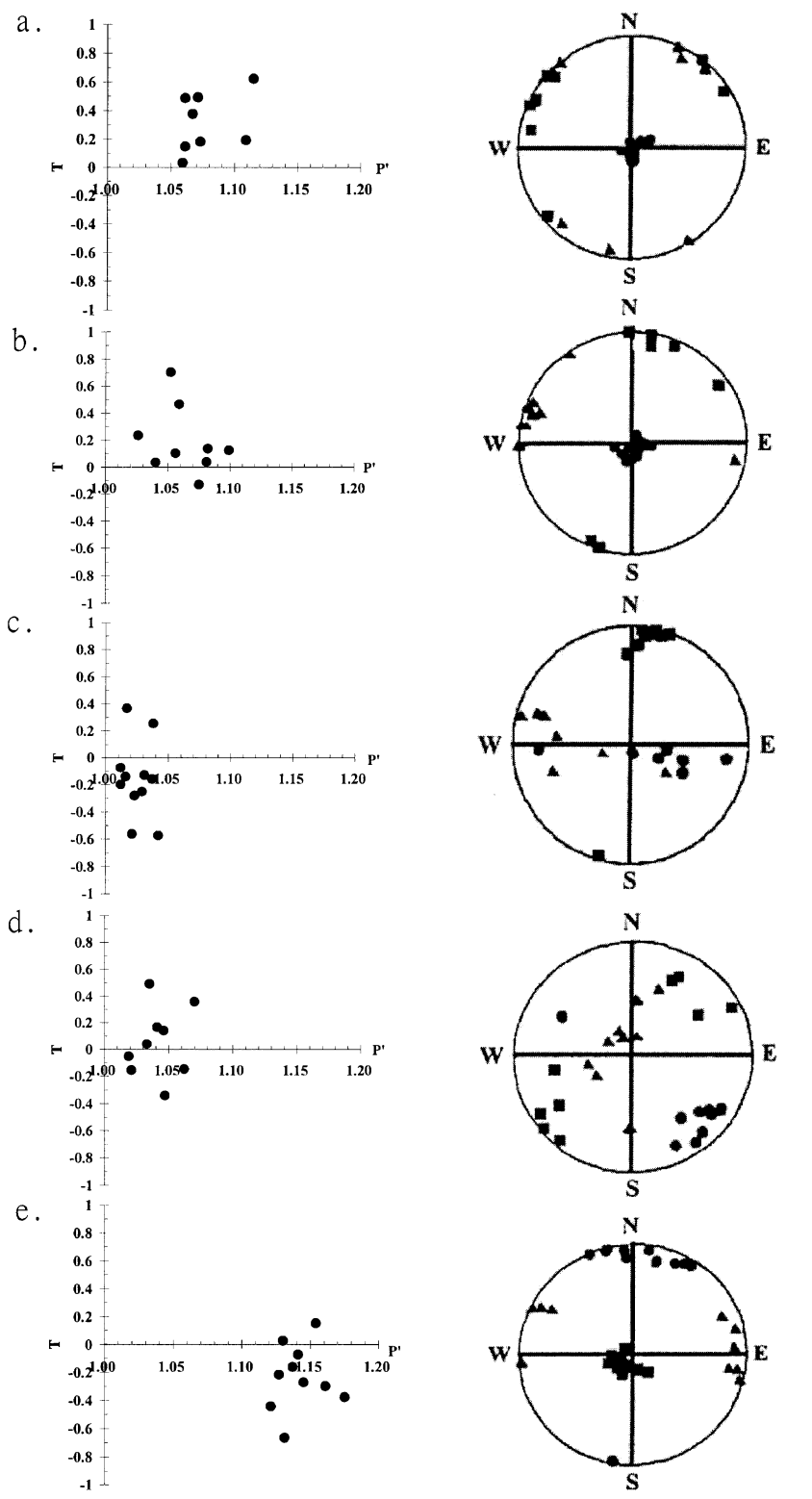

Fig. 5. Types of magnetic fabric identified in this study. a, b, c, d, e refer to the five types described in text, compatible with increasing tectonic strain. On left: P' vs. F plots. On right: stereo plots (Schmidt projection of lower hemisphere) of corresponding AMS principal axes (squares: $K_{\max }$, triangles: $K_{\text {int }}$ and circles: $K_{\min }$ ), shown after untilting. Further details in text.

of magnetic susceptibility of these samples were measured on the low-field (about 7 Gauss) Molspin Minisep system. For each specimen, three principal axes and their magnitudes (referred to as $K_{\max }, K_{\text {int }}$ and $K_{\min }$ ) describe the ellipsoid of AMS. Bedding attitudes (strike and dip) were accurately measured in the field at each sample location. Orientations of the three principal axes of AMS and its corresponding magnitudes is calculated before and after bedding corrections. No particular difficulty arose when making these geometrical corrections, because most folds in the area are cylindrical in type without any significant plunge. The diagrams and the numerical results presented in this paper are given after bedding correction.

Most fabrics revealed $K_{\min }$ axes perpendicular to the av- erage bedding plane of the corresponding site. This geometrical relationship indicates that the fabric resulting from syn-depositional and diagenetic flattening plays a significant role. It also suggests that a pronounced magnetic fabric of tectonic origin, if present, should have been acquired before or during the initial stages of folding: at least two axes of the AMS would have been found oblique to the bedding plane otherwise. $70 \%$ of these 352 sites allowed determination of magnetic lineation orientations. To quickly describe the shape of the AMS ellipsoid regardless of the absolute magnitudes of principal values, we made P' vs. T plots, as Fig. 5 shows.

\subsection{Types of magnetic fabrics}

Analyzing both the P' vs. T plots mentioned above and the orientations of the AMS axes, five different AMS types could be distinguished in our samples (Fig. 5). A typical depositional origin referred to as a-type for the AMS (Fig. 5a), the axes of minimum susceptibility, $K_{\min }$, are tightly grouped near the vertical (the normal to the backtilted bedding plane) while the other two axes have rather scattered orientations in the bedding plane. Another typical situation (b-type), is characterized by the probable influence of paleo-current or paleostress resulting in the presence of a magnetic lineation (Fig. 5b): each of the three sets of principal axes displays a consistent orientation, the $K_{\min }$ axes being again nearly normal to the bedding plane.

In the c-type (Fig. 5c), the axes of maximum susceptibility, $K_{\max }$, are well-grouped and lie in the bedding plane to form the magnetic lineation, while the other two axes have scattered positions within a girdle. This distribution is not easily explained by depositional process and/or compaction phenomena taken separately. It rather suggests a tectonic origin, with compression perpendicular to the $K_{\max }$ axis. In the d-type (Fig. 5d), the $K_{\min }$ axes are grouped, while the other two axes form a girdle; the $K_{\min }$ axes are parallel to, or make a low angle with, the bedding plane. This distribution also suggests that the sediments may have undergone some horizontal compression, along the trend of the $K_{\min }$ axes (i.e., NW-SE in Fig. 5d). Finally, the e-type is characterized by well grouped $K_{\max }$ axes nearly perpendicular to bedding, the other axes being rather scattered in the bedding plane. This may indicate that the sediments have undergone compression, but the direction of compression is poorly constrained. However, such a pattern may also result from the inversion of fabric caused by the predominance of single domain grains. Further investigation is needed to solve this ambiguity. Note that because our results were based on consideration of magnetic lineation, the d-type and e-type fabrics were not used (only b- and c-types were used).

\subsection{Orientation of magnetic lineations}

The distribution of the magnetic fabric patterns in the Tsengwenchi section changes depending on the depositional age of the samples. Major of the samples younger than $0.9 \mathrm{Ma}$ clearly show a-type fabric whereas the samples older than 0.9 Ma commonly show b-type and c-type fabrics. Magnetic lineations trending $\mathrm{N} 5^{\circ} \mathrm{E}$ to $\mathrm{N} 30^{\circ} \mathrm{E}$ prevail (Lee et al., $1990)$. They form a single group of trends, $\mathrm{N} 15^{\circ} \mathrm{E}\left( \pm 10^{\circ}\right)$ on average (Fig. 2).

In the Hokouchi section, most samples show magnetic fabric of types b or c. Types $d$ or e appeared in few sites, 
and less than $10 \%$ of sites showed an a-type fabric (Lee and Horng, 1993). Magnetic lineations in the Hokouchi section can be divided into two groups in trends (Fig. 3). The most common trend, $\mathrm{N} 15^{\circ} \mathrm{E}\left( \pm 10^{\circ}\right)$, is distributed in the entire section. About $20 \%$ of the sites have $\mathrm{N} 5^{\circ} \mathrm{W}$ to $\mathrm{N} 15^{\circ} \mathrm{W}$ trends; these sites are found in the western portion of the section, where the age of sediments is older than the middle Pliocene.

Only a, b, and c types of magnetic fabrics were found in the Erhjenchi section. They are randomly distributed, although the lineation is less pronounced in the upper section (a-type dominates in sediments younger than $0.9 \mathrm{Ma}$ ). About $50 \%$ of sites show b or $\mathrm{c}$ types. The NNE-SSW magnetic lineation is well represented (Fig. 4), but some deviation occurs relative to the other two sections, resulting in an average trend $\mathrm{N} 30^{\circ} \mathrm{E}$ $\left( \pm 10^{\circ}\right)$. Smaller subsets are also present, with some N-S trends and some NE-SW trends.

\subsection{Origin of magnetic anisotropy}

The magnetic fabrics of type $\mathrm{c}$ to type e (Fig. 5) are generally resulted from tectonic deformation. However, type $b$ may be generated due to tectonic deformation and/or depositional process. To investigate the possible origin of type $b$, we thus aimed at comparing the orientation data of both the sedimentary structure and the tectonic structure with those obtained from AMS analyses in order to determine what factor played the major role on the development of the AMS. Field observation effectively seemed to bring some support to the hypothesis of sedimentary origin, because paleochannels and sedimentary structure clearly related to paleocurrents were identified at several horizons in the sedimentary succession. In principle, depositional process may be responsible for the development of magnetic lineations because they imply preferential orientation of mineral grains. To evaluate their possible influence on the development of the observed magnetic lineations, the orientations of all these sedimentary features should be analyzed and then compares with the orientations of the magnetic lineations (the original trends and dips prior to folding being of course restored to stratigraphic coordinates). Déffontaines et al. (1994) analyzed the geometry of the late Pleistocene-Holocene drainage pattern in this large mudstone area of southwestern Taiwan, including our studied sections, and indicated no systematic flow directions.

The lack of geometrical relationships between complex depositional patterns and rather homogeneous trends of the AMS suggests that syn-depositional phenomena contributed little to the development of the magnetic anisotropy fabric, whereas the certainly influenced vertical minimum axis as mentioned before. The main result of our analysis is that the part of magnetic fabrics which cannot be explained only by the flattening resulting from compaction is consistent with development in deformation (Fig. 5b-d). That the syndepositional origin fails to account for most magnetic lineations observed certainly does not imply that these lineations are tectonic origin. Our conclusion is most magnetic lineations to be tectonic origin in the study area. It is supported by the geometrical consistency between the trends of these lineations and the orientations of the compressive tectonic regimes reconstructed based on independent structure analyses. For rocks with identifiable magnetic lineations, consistent trends are thus obtained for the inferred compression axes. These trends are summarized in the rose diagram of Fig. 6 . The in-

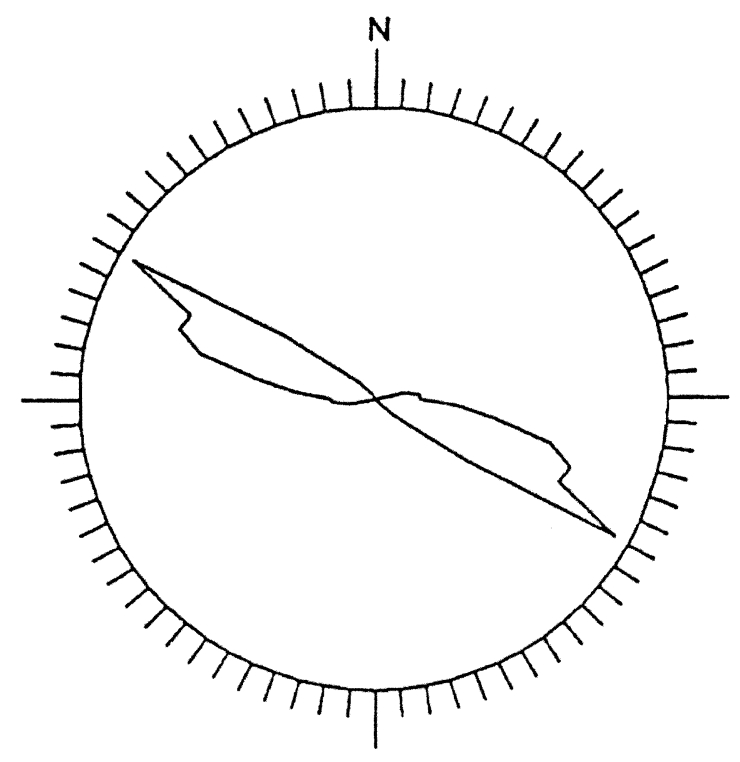

Fig. 6. Rose diagram of the directions of compression inferred from the complete set of reliable magnetic fabric determinations with probable tectonic significance (1,891 AMS determinations in 251 sites).

ferred trend of compression is $\mathrm{N} 105^{\circ}-120^{\circ} \mathrm{E}$ for more than $60 \%$ of data, and $90 \%$ of data fall in the range $\mathrm{N} 95^{\circ}-135^{\circ} \mathrm{E}$. In detail, $5 \%$ of data indicate a minor isolated group of $\mathrm{N} 80^{\circ}-$ $\mathrm{N} 85^{\circ} \mathrm{E}$ trends, whereas the $\mathrm{N} 120^{\circ}-140^{\circ} \mathrm{E}$ trends merge into the main azimuthal group. Although they are statistically significant, the two minor trends are difficult to detect in Fig. 6 because they are adjacent to the strongly dominating $\mathrm{N} 100^{\circ}-120^{\circ} \mathrm{E}$ trends.

It is shown, in a later section, that the orientations of magnetic lineations are generally consistent with the paleostress trends. A model involving tectonic deformation added to compaction explains the magnetic lineations. In summary, the NNE-SSW predominant trend of the magnetic lineations did not fit the depositional patterns well, but generally coincided with the structural grain of the region investigated, where major folds and thrusts strike NNE-SSW (Fig. 1). This suggested that the AMS had been influenced by tectonism. An independent tectonic analysis was thus undertaken, in order to better characterize the compressional deformation.

\section{Tectonic Analyses}

In the Tsengwenchi, Hokouchi and Erhjenchi sections, faults with observable slickenside lineations were measured at numerous sites. We determined paleostress tensors from fault slip data sets, based on the use of inversion methods thoroughly described elsewhere (Angelier, 1984, 1990). We thus reconstructed the principal paleostress axes $\sigma_{1}$ (maximum compressional stress), $\sigma_{2}$ (intermediate stress) and $\sigma_{3}$ (minimum stress), as well as the ratio $\Phi=\left(\sigma_{2}-\sigma_{3}\right) /\left(\sigma_{1}-\sigma_{3}\right)$ between principal stress differences. Other data, such as for the orientations of tension fractures, were also used in this tectonic study.

Particular attention was paid to the geometrical relation of fault-fracture systems to bedding attitudes and fold shapes. This was because the geometrical analysis allows distinction between pre-folding, syn-folding and post-folding brit- 

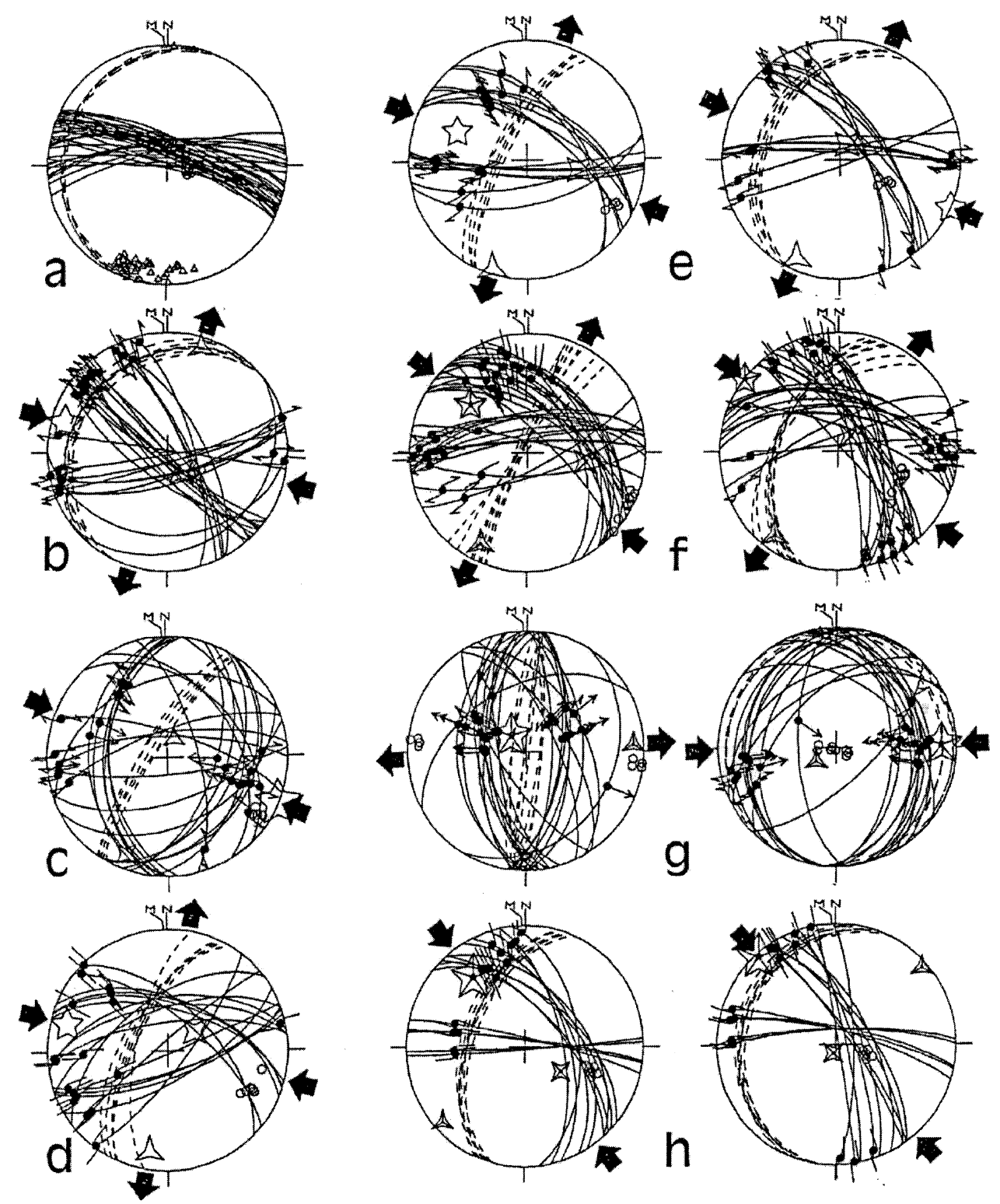

Fig. 7. Examples of paleostress reconstructions based on fault slip analyses. Schmidt projections, lower hemisphere. For a, b, c and d, present-day attitude shown. For e, f, g and h, present-day (on left) and backtilted (on right) attitudes shown. Fault-fractures planes as continuous lines; slikenside lineations shown as small dots with arrows indicating the sense of motion (double arrows for strike-slip, outward directed arrows for normal slip, inward directed arrows for reverse slip). Bedding planes shown as dashed lines, with poles to bedding as open dots. Inversion of fault slip data according to Angelier methods (1984 and 1990): direct inversion for b, c, $\mathrm{d}$ and e, 4-D search for $\mathrm{f}, \mathrm{g}$ and $\mathrm{h}$. Axes of maximum compressive stress $\left(\sigma_{1}\right)$, intermediate stress $\left(\sigma_{2}\right)$ and minimum stress $\left(\sigma_{3}\right)$ shown as 5, 4 and 3-branch stars respectively, with symbol size varing as a function of the ratio between principal stress differences, $\Phi=\left(\sigma_{2}-\sigma_{3}\right) /\left(\sigma_{1}-\sigma_{3}\right)$. Large black arrows indicate trends of compression and/or extension. For each stress determination, value of $\mathrm{F}$, number of fault slips used, trends and plunges of axes and misfit parameter listed in Table. (a) late WNW-ESE compression: tension joints, west of Erhjenchi section, Pleistocene Liushuang Formation (0.6-0.3 Ma); open triangles are poles to joints. (b) late WNW-ESE compression: strike-slip faults, same section and formation. (c) main WNW-ESE compression, post-folding stage: reverse and oblique slip faults, Erhjenchi section (sediments approx. 0.6-0.7 Ma old). (d) WNW-ESE compression, post-folding stage: strike-slip and oblique slip faults, Erhjenchi section (sediments approx. 1.7 Ma old). (e) NW-SE compression, syn-folding stage: tilted strike-slip faults, Erhjenchi section (Lower Gutingkeng Formation). (f) main WNW-ESE compression, syn-folding stage: tilted strike-slip faults, Erhjenchi section (sediments approx. 0.8-0.9 Ma old). (g) E-W compression, pre-folding stage: tilted reverse faults, eastern Tsengwenchi section (sediments approx. 3 Ma old). (h) NW-SE compression, pre-folding stage: Erhjenchi section (sediments approx. 0.6 Ma old).

tle tectonic events. By considering the attitudes of computed principal stress axes relative to bedding planes at sites where strata dips are steeper than $30^{\circ}$, it was possible to distinguish brittle systems that predate or postdate folding. In post-folding fracturing, one axis is usually nearly vertical $\left(\sigma_{2}\right.$ or $\sigma_{3}$, depending on whether strike-slip or reverse faulting mode dominated). Where pre-folding fracturing has occurred, this axis is not vertical, but approximately perpendicular to tilted bedding. It was even possible to identify fault systems which rotated during folding, as revealed by intermediate attitudes of computed axes. This approach had been applied by Angelier et al. $(1986,1990)$ to the Western Foothills and the Hsuehshan Range of Taiwan, in order to decipher the succession of events and to relate minor fault- 
fracture patterns with larger fold-and-thrust structures.

Examples of paleostress analyses are shown in Fig. 7. The simplest patterns of brittle features are found in the youngest formations. Two sites were located west of the Erhjenchi section, in the Pleistocene Liushuang Formation, of 0.3-0.6 Ma old or even younger. Both the tension joints (Fig. 7a) and the strike-slip faults (Fig. 7b) are consistent with a compression axis trending $\mathrm{N} 100^{\circ}-110^{\circ} \mathrm{E}$, perpendicular to the axis of gentle folding.

A stronger compression, with the same direction (N105 $\left.115^{\circ} \mathrm{E}\right)$, is revealed by sets of faults where reverse slip (Fig. 7c) or strike-slip (Fig. 7d) dominates. These two sites belong to the Erhjenchi section, in tightly folded layers west of the Hsiaokunshui anticline; the sediments affected are approximately 0.6-0.7 Ma (Fig. 7c) and 1.7 Ma old (Fig. 7d). Because the reconstructed compressional trends are nearly perpendicular to fold axes, most of the folding is attributed to the WNW-ESE compression. In Figs. 7a and b, the calculated compression axes are nearly horizontal while the bedding steeply dips in fold flanks; this indicates a final stage of compression, with the folds already formed.

The same $\mathrm{N} 110^{\circ} \mathrm{E}$ compression is revealed by the pattern of oblique-slip faults of Fig. 7e, in the lower Gutingkeng Formation of the Erhjenchi section. The computed compression axis dips significantly to the west; the minimum stress axis is nearly horizontal and parallel to bedding strike in fold flank (Fig. 7e, left). These faults developed as a conjugate strikeslip system during the fold development. A simple untilting process restores their initial attitude (Fig. 7e, right).

In a nearly vertical flank of the Hsiaokunshui anticline in the Erhjenchi section, a tilted strike-slip fault system affects sediments approximately during $0.8-0.9 \mathrm{Ma}$. It developed at an intermediate stage of folding (Fig. 7f). The original trend of compression is about $\mathrm{N} 130^{\circ} \mathrm{E}$, a common direction of compression in the eastern section. It was necessary to determine the age of this NW-SE compression relative to that of the major WNW-ESE compression. We took into consideration the fold geometry, the existence of angular unconformities in adjacent localities and the relative chronology between faulting and folding as indicated by geometrical and crosscutting relationships. We thus concluded that in the study area the $\mathrm{NW}$-SE compression is older than the widespread $\mathrm{N} 110^{\circ} \mathrm{E}$ compression.

In a vertical fold flank west of the Wushantou thrust, in the eastern Tsengwenchi section, the sediment ages average $3 \mathrm{Ma}$. The present-day pattern resembles a system of conjugate normal faults (Fig. 7g, left). The faults in fact developed prior to any folding, as reverse faults under E-W compression (Fig. $7 \mathrm{~g}$, right). This $\mathrm{N} 85^{\circ} \mathrm{E}$ compression only affects the oldest formations, and occurred early in the structural development of the area.

A situation of pre-folding compression is also illustrated in Fig. 7h for the NW-SE compression: strike-slip faults developed in nearly horizontal or shallowly dipping layers prior to the development of the main folding event with NNESSW axes. This example provides further evidence that the $\mathrm{N} 130^{\circ} \mathrm{E}$ compression predated the $\mathrm{N} 110^{\circ} \mathrm{E}$ one. The sediments affected in the case of Fig. $7 \mathrm{~h}$ are approximately 0.6 Ma old, still younger than those of Fig. $7 \mathrm{f}$. A long time span cannot have taken place between these events.
We conclude that a major compression trending $\mathrm{N} 100^{\circ}-$ $110^{\circ} \mathrm{E}$ affected the area of Fig. 1 . To the north (Tsengwenchi and Hokouchi sections), this compression trends $\mathrm{N} 100^{\circ} \mathrm{E}$ $\left( \pm 15^{\circ}\right)$. It affects sediments which range in age from about $3 \mathrm{Ma}$ (and older) to $0.9-0.7 \mathrm{Ma}$ (younger formations absent) and is related to the last stages of folding. Observation of angular unconformities, and consideration of fold orientations below and around these uncomformities, suggests that a peak stage in this $\mathrm{N} 100^{\circ} \mathrm{E}$ compression occurred during $0.9-$ 1.0 Ma (although the same compression had certainly begun before and has continued later). To the south (Erhjenchi section), this major compression trends $\mathrm{N} 105^{\circ} \mathrm{E}\left( \pm 5^{\circ}\right)$, resulted in most of the folding, and affects sediments which range in age from about $0.9 \mathrm{Ma}$ (and older) to $0.6-0.3 \mathrm{Ma}$. The poor record of this compression in the upper formations indicate that most of the folding occurred before about 0.6-0.7 Ma .

An older $\mathrm{N} 120^{\circ}-140^{\circ} \mathrm{E}$ trending compression (Fig. $7 \mathrm{f}$ and h) was reconstructed in both the northern and southern sections. To the north, it trends mainly $\mathrm{N} 120^{\circ}-135^{\circ} \mathrm{E}$ and affects formations approximately 1.9-2.0 Ma. To the south, it trends $\mathrm{N} 120^{\circ}-140^{\circ} \mathrm{E}$ (mainly $130^{\circ}-135^{\circ}$ ) and affects formations ranging in age from 1.7 to $1.0 \mathrm{Ma}$ (and older). In both cases, it unambiguously predates the main folding event. However, in the Erhjenchi section, this NW-SE trending compression is probably related to part of folding; syn-folding $\mathrm{N} 120^{\circ}-140^{\circ} \mathrm{E}$ compression could be identified in sediments older than about 1.5 Ma.

The other compression found in these sections trends $\mathrm{N} 085^{\circ} \mathrm{E}$ on average (Fig. $7 \mathrm{~g}$ ), and only affects formations older than 2.5 Ma. It predates the major folding and affects the eastern area, which suggests an inner origin in the belt.

\section{Discussion and Conclusion}

To determine the tectonic significance of the magnetic fabrics recorded in the southwestern Foothills of Taiwan (Fig. 1), we carried out systematic comparisons between the results of AMS studies (Figs. 2-6) and the results directly provided by structural analyses of fold and fault-fracture structure systems (Fig. 7 and Table 1). Similar geometrical comparisons are shown that the depositional process were unable to account for the magnetic lineation trends. We then considered a model of increasing compressional strain, compatible with the types of magnetic fabrics illustrated in Fig. 5, and we checked its capacity to account for both the AMS and tectonic data. The compression inferred from AMS analyses generally lies in the $\mathrm{N} 100^{\circ}-120^{\circ} \mathrm{E}$ direction (Fig. 6). This is in close agreement with the results of both the new local deformation analysis presented in this paper and the earlier studies of the surrounding Foothills: a WNW-ESE compression dominated during the last Taiwan collision (Angelier et al., 1986; Chu, 1990; Lee, 1994).

A major conclusion of this study is the strong general consistency between the trends of orientation in AMS analyses (Figs. 2-4, Fig. 6) and the trends of compression revealed by fault slip data analyses in the same sections (examples in Fig. 7, and Table 1). In terms of magnetic fabrics, the inferred compressional trends are perpendicular to the directions of magnetic lineations for types $b$ and c, or approximately parallel to the normal vector of flattening for type d (Fig. 5). The directions of magnetic lineations $\left(K_{\max }\right.$ axes) have tectonic 
Table 1. Examples of results of fault slip data inversion (first column refers to Fig. 7). Trends and plunges of computed principal paleostress axes in degrees. Ratio $\Phi$ defined in text. Average misfit angle given in degrees. N, number of fault slips. For location and stratigraphic ages, see Fig. 7 and text. Attitudes of principal paleostress axes after untilting given on right, for sites where folding continued after faulting (compare with Fig. 7).

\begin{tabular}{|c|c|c|c|c|c|c|c|c|c|c|c|c|c|c|c|}
\hline \multirow{2}{*}{$\begin{array}{c}\text { Ref. } \\
\text { In } \\
\text { Fig. } \\
\text { b }\end{array}$} & \multicolumn{2}{|c|}{$\begin{array}{l}\text { trend and } \\
\text { plunge of } \\
\sigma_{1} \text { axis }\end{array}$} & \multicolumn{2}{|c|}{$\begin{array}{l}\text { trend and } \\
\text { plunge of } \\
\sigma_{2} \text { axis }\end{array}$} & \multicolumn{2}{|c|}{$\begin{array}{l}\text { trend and } \\
\text { plunge of } \\
\sigma_{3} \text { axis }\end{array}$} & \multirow{2}{*}{$\begin{array}{c}\text { Ratio } \\
\Phi \\
0.14\end{array}$} & \multirow{2}{*}{$\begin{array}{c}\text { Misfit } \\
\text { angle }\end{array}$} & \multirow{2}{*}{$\begin{array}{l}\mathrm{N} \\
\\
27\end{array}$} & \multicolumn{2}{|c|}{$\begin{array}{l}\text { tr. and pl. } \\
\text { of } \sigma_{1} \text { axis } \\
\text { backtilted }\end{array}$} & \multicolumn{2}{|c|}{$\begin{array}{l}\text { tr. and pl. } \\
\text { of } \sigma_{2} \text { axis } \\
\text { backtilted }\end{array}$} & \multicolumn{2}{|c|}{$\begin{array}{l}\text { tr. and pl. } \\
\text { of } \sigma_{3} \text { axis } \\
\text { backtilted }\end{array}$} \\
\hline & 291 & 14 & 141 & 75 & 23 & 7 & & & & & & & & & \\
\hline $\mathrm{c}$ & 113 & 4 & 19 & 45 & 207 & 45 & 0.02 & 9 & 24 & & & & & & \\
\hline $\mathrm{d}$ & 287 & 13 & 45 & 65 & 192 & 22 & 0.40 & 10 & 18 & & & & & & \\
\hline $\mathrm{e}$ & 292 & 37 & 101 & 53 & 198 & 5 & 0.56 & 9 & 16 & 114 & 0 & 24 & 79 & 204 & 11 \\
\hline $\mathrm{f}$ & 309 & 37 & 99 & 49 & 207 & 15 & 0.48 & 10 & 32 & 307 & 1 & 41 & 77 & 217 & 13 \\
\hline $\mathrm{g}$ & 316 & 75 & 179 & 11 & 87 & 10 & 0.14 & 6 & 24 & 89 & 14 & 356 & 9 & 234 & 74 \\
\hline $\mathrm{h}$ & 323 & 29 & 124 & 60 & 228 & 8 & 0.05 & 3 & 15 & 319 & 3 & 197 & 84 & 49 & 5 \\
\hline
\end{tabular}

significance for the sites having magnetic fabrics of types $b$ and $\mathrm{c}$, and the trend of compression is perpendicular to that of the magnetic lineation (after untilting). For type d, this trend is that of the average $K_{\min }$ axis, perpendicular to the girdle. Both the geometrical incompatibility with depositional patterns and the good fit with the results of independent tectonic analyses supported our tectonic interpretation of the magnetic lineations.

In terms of regional tectonic evolution, the timing between the WNW-ESE, W-E and NW-SE compressions were not firmly established (Chu, 1990). This suggests complex stress partitioning during the Quaternary rather than a definite succession of tectonic events with typical trends (Lacombe et al., 1993). In terms of local AMS distribution, and considering the stratigraphic ages of the formations (Figs. 2-4), it, however, appears that the different AMS directions are time and space dependent. This is also the case for the local fault slip analyses presented in this paper. Discrepancies remain minor, within the range of reasonable uncertainties for both the trends and the age determinations.

The tectonic history of the area studied is summarized as follows:

(1) A N $080^{\circ}-090^{\circ} \mathrm{E}$ compression probably occurred before $2.5 \mathrm{Ma}$. It is revealed by local tectonic observations in the northern sections where it affects sediments older than 2.5 Ma (Tsengwenchi). It is consistently revealed by AMS analyses in sediments older than the middle Pliocene of the Hokouchi section. This compression affected flat-lying sediments which subsequently suffered folding and faulting. It is likely that this compression was stronger to the east, while the area studied was a simple foreland with almost undeformed formations. However, in southwestern Taiwan, analyses of Quaternary brittle tectonics (Lacombe et al., 1993) and focal mechanisms of earthquakes (Yeh et al., 1991) revealed a complex pattern of stress (including E-W compression). Based on these tectonic observations, our conclusion is that the $\mathrm{N} 080^{\circ}-090^{\circ} \mathrm{E}$ compression represents a relatively old event, may be of local value, and, in any case, should not be extrapolated to the whole western Foothills of Taiwan.

(2) A N $130^{\circ}-140^{\circ} \mathrm{E}$ compression (with few additional evidences for a $\mathrm{N} 150^{\circ} \mathrm{E}$ compression) may have occurred ap- proximately $1 \mathrm{Ma}$ ago in the area studied. It was recorded in sediments older than 1.0 Ma in the southern section. This compression only left a minor magnetic lineation in some of our samples, because the total deformation remained limited and also because of the strong overprinting due to the later compression. To the north, the youngest formations affected are approximately $1.5 \mathrm{Ma}$ old. This NW-SE compression generally predates most of folding. However, it is related to part of folding in the Tsengwenchi section (with N130 $135^{\circ} \mathrm{E}$ trends before this folding stage, and $\mathrm{N} 120^{\circ}-135^{\circ} \mathrm{E}$ during it). Distinguishing between this NW-SE compression and the later WNW-ESE compression is locally difficult, especially in the areas where intermediate trends are present (around $\mathrm{N} 120^{\circ} \mathrm{E}$ ).

(3) The paroxysmal compression occurred at about 0.91.0 Ma. Its trends are rather homogeneous $\left(\mathrm{N} 100^{\circ}-110^{\circ} \mathrm{E}\right)$, despite some local deviations as in the Erhjenchi section (local $\mathrm{N} 120^{\circ} \mathrm{E}$ trends). This major event is responsible for the main folding and thrusting, which strongly affects sediments older than 0.9-1 Ma in the area studied. Major folds and thrusts trending $\mathrm{N} 010^{\circ}-020^{\circ} \mathrm{E}$ (Fig. 1) are perpendicular to compression. The magnetic fabric was deeply influenced by this event. The age of the peak compression is constrained by the magnetostratigraphic ages: in the southern section (Erhjenchi), sediments younger than 0.7 Ma showed little or no magnetic lineation. In sediments younger than 0.9 Ma, the magnetic lineation is more pronounced to the south than to the north, consistent with a stronger recent WNW-ESE compression to the south.

In summary, the interpretation of the AMS data, supported by independent results of structural analysis, strongly suggests that a widespread $\mathrm{N} 100^{\circ}-110^{\circ} \mathrm{E}$ compression, early Quaternary in age, affected this area until about $0.9 \mathrm{Ma}$ and decreased later. In detail, traces of an earlier NW-SE compression were found, and some E-W compression had occurred before. Comparisons between the sections suggest that the major $\mathrm{N} 100^{\circ}-110^{\circ} \mathrm{E}$ compression occurred (or persisted) later to the south. This conclusion is not surprising in light of the migration of the collision from north to south along the Taiwan belt.

In previous magnetic studies, it was pointed out that a 
diachronic clockwise rotation had occurred in the Coastal Range area of eastern Taiwan, on the opposite side of the mountain belt (Lee et al., 1990, 1991a). This rotation propagated southward while the units of the Luzon Arc were successively colliding against Taiwan (resulting in the Coastal Range); it occurred in the northern part about $3 \mathrm{Ma}$ ago, in the middle part about $2 \mathrm{Ma}$ ago and finally in the southern part about $1 \mathrm{Ma}$ ago. Taking into account both the magnetic data and the tectonic information, Lee et al. (1991a) proposed that just before the rotation of units, the compressional paleostress had been trending E-W, and thus changed to a $\mathrm{N} 100^{\circ}-120^{\circ} \mathrm{E}$ direction during and after rotation. Comparing the results of our present study to those the eastern Coastal Range, they display some similarity.

However, a difference between the situations east and west of Taiwan lies in the fact that not only the paleomagnetism failed to reveal large Plio-Quaternary rotations of units in the southwestern Foothills, but also the most reliable data suggest that little Plio-Pleistocene rotation has occurred. In the Coastal Range, the apparent counterclockwise rotation of the compression results from both the clockwise rotation of the thrust units and the counterclockwise deviation of stress (increasing with mechanical coupling). In the southwestern Foothills, the latter factor is predominant. In the absence of large rotation, it explains the change from $\mathrm{N} 130^{\circ}-140^{\circ} \mathrm{E}$ to $\mathrm{N} 100^{\circ}-110^{\circ} \mathrm{E}$ compressional trends in the youngest parts of the Hokouchi and Tsengwenchi sections. This counterclockwise change may be related to the presence of the Peikang High, a zone of uplifted foreland basement located northwest of the area studied (Fig. 1). This Peikang High strongly influenced the deformation in the fold-and-thrust units of the belt (Lu and Malavieille, 1994) and resulted in large stress deviations (Lee, 1994; Hu, 1995). This phenomenon may have repeatedly occurred during the late Pliocene and the Quaternary. Such repetition is suggested by the presence of the earlier E-W compression found in an inner position within the units of the southwestern Foothills (as deduced from both the AMS recorded in the oldest formations of the Hokouchi and Erhjenchi sections and the analysis of the fault slip data). Increasing complexity resulted from stress partitioning, especially where strike-slip faults trending obliquely are present.

The magnetic fabric of tectonic origin is poorly marked, or absent, in the formations younger than about $0.9 \mathrm{Ma}$ to the north (Tsengwenchi section). It is present to the south (Erhjenchi section), where it decreased only after about $0.7 \mathrm{Ma}$. This contrast indicates that the $\mathrm{N} 100^{\circ}-110^{\circ} \mathrm{E}$ compression has propagated southward. Between 0.9 and $0.7 \mathrm{Ma}$ ago (approximately), because of this migration, the compressional stress probably became too weak in the northern section to induce development of a magnetic fabric in the youngest sediments, whereas to the south it was strong enough.

In the Plio-Quaternary mudstones of the southwestern Taiwan Foothills, combined analyses of AMS and brittle tectonics provided significant insights for the tectonic evolution. Our results indicated that whereas compaction resulted in marked flattening of the AMS, most magnetic lineations of the Plio-Quaternary sections studied are tectonic in origin. This conclusion resulted from two types of observations. First, no systematic geometrical relationship could be found in the study area between the orientations of the magnetic lineations revealed by our AMS analyses and the orientations of paleocurrents, sediment supply directions and even slump structures (which in addition display large scatter whereas AMS trends show systematic grouping in few directions). Second, the predominant trends of magnetic lineations were found geometrically consistent with the orientation of the compressional tectonic regimes reconstructed independently based on structural analysis and fault slip data inversion.

The main tectonic source of anisotropy in the study area was the WNW-ESE regional compression, which also resulted in major Quaternary folds and thrusts. In addition, two secondary trends of compression, E-W and NW-SE, were recognized, also consistent with tectonic evidence. Although this is not the aim of this paper, it is important to observe that the regional distribution of these compressions in space and time, as identified for the period of the last $2 \mathrm{Ma}$, is closely related to the southward migration of the Taiwan collision.

Acknowledgments. The magnetic study was supported by the $\mathrm{Na}-$ tional Science Council of Taiwan (grants NSC82-0202-M-001-108, NSC83-0202-M-001-059 and NSC84-2111-M-001-012). The structural analysis was supported by the Institut Français à Taipei and the National Science Council within the framework of the SinoFrench cooperation in Earth Sciences. The help from Dr. Lee JianCheng and Dr. Hu Jyr-Ching for improving maps is acknowledged. Very useful comments were done by the referees, Dr. K.-P. Kodama and Dr. W. Soh.

\section{References}

Angelier, J., Tectonic analysis of fault slip data sets, J. Geophys. Res., 89(B7), 5835-5848, 1984

Angelier, J., Inversion of field data in fault tectonics to obtain the regional stress, III. A new rapid direct inversion method by analytical means, Geophys. J. Int., 103, 363-376, 1990.

Angelier, J., E. Barrier, and H. T. Chu, Plate collision and paleostress trajectories in a fold-thrust belt: the Foothills of Taiwan, Tectonophys., 125 , 161-178, 1986.

Angelier, J., F. Bergerat, H. T. Chu, and T. Q. Lee, Tectonic-paleomagnetic analyses and the evolution of a curved collision belt: the Hsuehshan Range, northern Taiwan, Tectonophys., 183, 77-96, 1990.

Barrier, E. and J. Angelier, Active collision in eastern Taiwan: the Coastal Range, Tectonophys., 125, 1-3, 39-72, 1986.

Chamley, H., J. Angelier, and L. S. Teng, Tectonic and environmental control of the clay mineral sedimentation in the late Cenozoic orogen of Taiwan, Geodinamica Acta, Paris, 6(2), 135-147, 1993.

Chang, L. S., Definition of the Liushuang Formation, Mem. Geol. Soc China, 1, 189-192, 1962 (in Chinese).

Chi, W. R., The late Neogene nannobiostratigraphy in the Tainan Foothills region, southern Taiwan, Petrol. Geol. Taiwan, 15, 89-125, 1978.

Chu, H. T., Néotectonique cassante et collision Plio-Quaternaire à Taiwan, Mem. Sc. Terre Univ. P. et M. Curie, Paris, 90-28, 292 pp., 1990.

Déffontaines, B., J. C. Lee, J. Angelier, J. Carvalho, and J. P. Rudant, New geomorphic data on the active Taiwan orogen: a multisource approach, J. Geol. Res., 99(B10), 20243-20266, 1994.

Graham, J. W., Significance of magnetic anisotropy in Appalachian sedimentary rocks, in The Earth Beneath the Continents, edited by J. S. Steinhard et al., pp. 627-648, Geophys. Monogr. 10, AGU, 1966.

Henry, B., Studies of microtectonics, anisotropy of magnetic susceptibility and paleomagnetism of the Permian Dome de Barrot (France): Paleotectonics and paleosedimentological implications, Tectonophys., 17, 61-72, 1973

Ho, C. S., A synthesis of the geologic evolution of Taiwan, Tectonophys., 125, 1-16, 1986.

Ho, C. S., An Introduction to The Geology of Taiwan: Explanatory Text of the Geologic Map of Taiwan, 2nd edition, 225 pp., Ministry of Economic Affairs, R.O.C., 1988

Horng, C. S., Magnetic mineralogy and magnetostratigraphic studies of the Tsengwenchi and Erhjenchi sections, southwestern Taiwan, Ph.D. dissertation, Inst. of Oceano., National Taiwan Univ., 323 pp., 1991. 
Horng, C. S., J. C. Chen, and T. Q. Lee, Variation in magnetic minerals from two Plio-Pleistocene marine-deposited sections, southwestern Taiwan, $J$. Geol. Soc. China, 35(4), 323-335, 1992.

Hrouda, F., The strain interpretation of magnetic anisotropy in rocks of the Nizky Jesenik Mountains (Czechoslovakia), Sbor. Geol. Ved, UG 16, 27-62, 1979.

Hrouda, F. and F. Janak, The changes in shape of the magnetic susceptibility ellipsoid during progressive metamorphism and deformation, Tectonophys., 34, 135-148, 1976.

Hrouda, F., F. Janak, and L. Rejl, Magnetic anisotropy and ductile deformation of rocks in zones of progressive regional metamorphism, Gerl. Beitr. Geophys., 87, 126-134, 1978.

$\mathrm{Hu}$, J. C., Modélisation numérique et analyse tectonique régionale: le cas de Taiwan, Mem. Sc. Terre Univ. P. et M. Curie, Paris, no95-18, 268 pp., 1995 (in French).

Kissel, C., E. Barrier, C. Laj, and T. Q. Lee, Magnetic fabric in "undeformed" marine clays from compressional zones, Tectonics, 5, 769-781, 1986.

Kligfield, R., W. Lowrie, and I. W. D. Dalziel, Magnetic susceptibility as a strain indicator in the Sudbury Basin, Ontario, Tectonophys., 40, 287308, 1977.

Kligfield, R., W. H. Owens, and W. Lowrie, Magnetic susceptibility anisotropy, strain, and progressive deformation in Permian sediments from the Maritime Alps (France), Earth Planet. Sci. Lett., 55, 181-189, 1982.

Lacombe, O., J. Angelier, and P. Laurent, Les macles de la calcite, marqueurs des compressions récentes dans un orogène actif: l'exemple des calcaires récifaux du sud de Taiwan, C. R. Acad. Sc. Paris, 316(II), 1805-1813, 1993.

Lee, J. C., Structure et déformation active d'un orogène: Taiwan, Mem. Sc. Terre Univ. P. et M. Curie, Paris, no94-17, 328 pp., 1994.

Lee, T. Q., Evolution tectonique et géodynamique neogène et quaternaire de la chaîne côtière de Taiwan: apport du paléomagnètisme, Mem. Sc. Terre Univ. P. et M. Curie, Paris, no89-03, 328 pp., 1989.

Lee, T. Q. and C. S. Horng, Magnetic fabric analysis of the Plio-Pleistocene Tsengwenchi sedimentary rock sequence, southern Taiwan and its tectonic implications, Proc. Geol. Soc. China, 33(4), 373-389, 1990.

Lee, T. Q. and C. S. Horng, Magnetic fabric analysis of late Neogene Hok- ouchi sedimentary sequence, southern Taiwan and its tectonic implications, J. Geol. Soc. China, 36(1), 1-14, 1993.

Lee, T. Q., C. Kissel, C. Laj, C. S. Horng, and Y. T. Lue, Magnetic fabric analysis of the Plio-Pleistocene sedimentary formations of the Coastal Range of Taiwan, Earth Planet. Sci. Lett., 98, 23-32, 1990.

Lee, T. Q., C. Kissel, E. Barrier, C. Laj, and W. R. Chi, Paleomagnetic evidence for a diachronic clockwise rotation of the Coastal Range, eastern Taiwan, Earth Planet. Sci. Lett., 104, 245-257, 1991a.

Lee, T. Q., J. Angelier, H. T. Chuand, and F. Bergerat, Rotations in the northeastern collision belt of Taiwan: preliminary results from paleomagnetism, Tectonophys., 199, 109-120, 1991 b.

Lu, C. Y. and K. J. Hsu, Tectonic evolution of the Taiwan mountain belt, Petrol. Geol. Taiwan, 29, 15-35, 1992.

$\mathrm{Lu}, \mathrm{C}$. Y. and J. Malavieille, Oblique convergence, indentation and rotation tectonics in the Taiwan mountain belt: insights from experimental modelling, Earth Planet. Sci. Lett., 121, 477-494, 1994.

Lu, C. Y., J. Angelier, H. T. Chu, and J. C. Lee, Contraction, transcurrent, rotational and extensional, tectonics: a case study in northern Taiwan, Tectonophys., 246, 129-146, 1995.

Lue, Y. T., T. Q. Lee, and Y. Wang, Paleomagnetic study on the collisionrelated bending of the fold-thrust belt, northern Taiwan, J. Geol. Soc. China, 38(3), 215-227, 1995.

Stach, L. W., Stratigraphic subdivision and correlation of the upper Cenozoic sequence in the foothills region east of Chiayi and Hsinying, Taiwan, China, Proc. Symp. Petrol. Geol. Taiwan, 177-230, 1957.

Suppe, J., Mechanics of mountain building and metamorphism in Taiwan, Mem. Geol. Soc. China, 4, 67-89, 1981.

Teng, L. S., Geotectonic evolution of late Cenozoic arc-continent collision in Taiwan, Tectonophys., 183, 57-76, 1990.

Tsai, Y. B., Seismotectonics of Taiwan, Tectonophys., 125, 17-37, 1986.

Yeh, Y. H., E. Barrier, C. H. Lin, and J. Angelier, Stress tensor analysis in the Taiwan area from focal mechanisms of earthquakes, Tectonophys., 200, 267-280, 1991.

T.-Q. Lee (e-mail: tqlee@earth.sinica.edu.tw) and J. Angelier 